\title{
The Reversal of the Gender Gap in Education and its Consequences for Family Life
}

\author{
Jan Van Bavel ${ }^{1}$ \\ Christine Schwartz ${ }^{2}$ \\ Albert Esteve3
}

Forthcoming in Annual Review of Sociology, vol. 44, 2018

\begin{abstract}
While men tended to receive more education than women in the past, the gender gap in education has reversed in recent decades in most Western and many non-Western countries. We review the literature about the implications for union formation, assortative mating, the division of paid and unpaid work, and union stability in Western countries. The bulk of the evidence points to a narrowing of gender differences in mate preferences and declining aversion to female status-dominant relationships. Couples in which wives have more education than their husbands now outnumber those in which husbands have more. While such marriages were more unstable in the past, existing studies indicate that this is no longer true. In addition, recent studies show less evidence of gender display in housework when wives have higher status than their husbands. Despite these shifts, other research documents the continuing influence of the breadwinner-homemaker model of marriage.
\end{abstract}

\footnotetext{
${ }^{1}$ Centre for Sociological Research, University of Leuven (KU Leuven), corresponding author: Jan.VanBavel@kuleuven.be

${ }^{2}$ Department of Sociology, University of Wisconsin-Madison

3 Center for Demographic Studies, Barcelona
} 


\section{INTRODUCTION}

While men have historically received more education on average than women, women began to outperform men in tertiary education in the last decades of the twentieth century in a growing number of high and middle income countries (Schofer \& Meyer 2005), including the US (DiPrete \& Buchmann 2006; 2013), almost all European countries (Van Bavel 2012; De Hauw et al. 2017) as well as many non-western countries (Esteve et al. 2012; 2016). In American and European media and popular books, the reversal of the gender gap in education (henceforth referred to as RGE) has given rise to accounts of the "decline of men" and troubles of college educated women finding "Mr. Right" (e.g., Rosin 2012; Mundy 2012; Birger 2015; Whitehead 2002; Beck 2011).

Two main concerns have been highlighted. First, as the number of highly educated women has grown, their chances of marrying may diminish given the presumed preference for relationships in which husbands have higher status than their wives. And, second, when highly educated women do form relationships in which they have higher socio-economic status, their relationships may suffer. This paper will evaluate the evidence for these claims by reviewing the literature on emerging patterns and trends in union formation and on relationship outcomes.

We focus on the implications of RGE for family and relationship dynamics among heterosexual couples in Western countries. First, we review recent research about trends in union formation and assortative mating. Next, we discuss how emerging patterns of union formation may affect the gendered division of paid and unpaid work among couples as well as relationship satisfaction and union (in)stability. For convenience, we refer to male and female partners in a co-resident union as "husbands" and "wives" but many studies also include unmarried cohabiting partners.

Our review considers the potential consequences of RGE for family life given that no comprehensive review of this topic has thus far been conducted. However, we acknowledge that the causal arrow may run in the opposite direction and/or both RGE and family patterns may be jointly determined by other broad shifts such as changes in the economic opportunities available to young men and women, technological shifts, and rising individualism and egalitarian ideals (Goode 1963; Goldscheider et al. 2015; Ruggles 2015). Patterns of family life also affect men's and women's educational attainment, and thus by extension may help explain RGE. Explanations for RGE have 
been the focus of other reviews (see Buchmann, DiPrete, and McDaniel 2008) and thus are not covered here.

\section{THE EDUCATION-SPECIFIC PARTNERING SQUEEZE}

Because union formation is affected both by the opportunities to meet potential partners and by individuals' preferences for mates (Kalmijn 1998; Schwartz 2013), the impact of RGE will depend on its implications for these two factors and their interplay (Van Bavel 2012).

Studies of the effects of partner availability on marriage rates have a long tradition in family demography, where variation in availability has typically been indexed by sex ratios (Hajnal 1953; Glick et al. 1963; Akers 1967; Fossett \& Kiecolt 1991; Angrist 2002). The classic "marriage squeeze" hypothesis states that marriage opportunities are depressed when faced with a shortage of marriageable members of the opposite sex (Glick et al. 1963; Akers 1967; Schoen 1983). Unbalanced sex ratios are a concern in many parts of the world, often framed as a "missing women" problem in case of a female deficit (e.g. Sen 1992; Attané 2006; Das Gupta 2006; Kashyap et al. 2015) or as a matter of "too many women" (Guttentag \& Secord 1983). If the strength of individuals' preferences for relationships in which husbands are at least as highly educated as wives has remained fixed, then RGE means that more people will remain

single or settle for a less preferred option than in the past. Alternatively, mate preferences may have changed. For example, as highly educated women have become economically more independent, they may care less about men's education or earning potential and may attach more importance to "cute butts and housework" (Press 2004). What does the evidence suggest about change and variation in preferences?

\section{Mate preferences and mate choice}

The bulk of empirical studies show that men's and women's preferences for mates have been converging in the West (see Zentner \& Eagly 2015 for a review, Schmitt 2012 for criticism). Buss et al. (2001) report that the importance both men and women attach to a mate's physical attractiveness in the US increased between 1939 and 1996. Also, both men and women, but especially men, increasingly value finding a mate with good financial prospects. Overall, there has been a clear convergence between the sexes in the ordering of the importance of mate qualities (Buss et al. 2001). Consistent with the hypothesis that women's increased economic status is associated with these trends, 
another study using US data found that women who are financially independent attribute relatively less importance to good financial prospects and more to physical attractiveness compared to women who are financially less independent (Moore, Cassidy and Perrett 2010).

There is also evidence suggesting that men's and women's aversion to female status dominant relationships has declined. Willinger (1993) surveyed male college students in the US and found that 60\% reported in 1990 that "it wouldn't bother me at all" if their female partners outearned them, up from $41 \%$ in 1980. Likewise, Esteve et al. (2016) report that across countries in the 2010-2014 World Values Survey, younger cohorts are more likely than older cohorts to disagree with the statement "If a woman earns more money than her husband, it's almost certain to cause problems." These studies suggest that, in addition to convergence in mate selection preferences, the aversion to female status-dominant relationships may have declined.

The gender gap in mate preferences has been found to narrow with national measures of gender equality. This holds for preferences related to education, intelligence, earnings prospects, and particularly for age preferences. For some criteria, in more gender equal countries, sex differences in mate preferences have even reversed. For example, in Finland, men report intelligence and education to be a more important criterion for mate selection than do women. Also, in both Finland and Germany, men state that they consider good housekeeping skills as a less important selection criterion than women do for men (Zentner \& Mitura 2012).

Although several studies point to gender convergence in mate preferences, other studies suggest that overall patterns are still in line with the male breadwinner-female homemaker model of marriage. In a number of experiments conducted around 2010 in the US and the Netherlands, Ratliff and Oishi (2013) demonstrated that men's implicit self-esteem is lower when they are confronted with their romantic partner's success, while the same does not hold for women's self-esteem when confronted with their male partner's success. This could imply that men avoid mates who may outperform them, at least among the university undergraduates who formed the bulk of the participants in the experiments, while the same would not hold for their female counterparts. Speed dating experiments and online dating studies conducted in the US support the idea that men avoid female partners with characteristics associated with economic success such as high educational attainment and ambition, at least in the early 2000s, when the data were collected (Fisman et al. 2006; Hitsch et al. 2010). It 
is not clear whether this also holds for long-term relationships. Preferences may differ for short-term versus long-term relationships (Stewart-Williams and Thomas 2013).

Similarly, Bursztyn et al. (2017) concluded from experimental research that highly educated women may avoid signaling professional ambition because it could be penalized in the marriage market. In 2016, they asked newly-admitted students in an elite US MBA program about their job and salary preferences, and informed a randomly selected half that their answers would be shared with classmates. Single and non-single women answered similarly when they thought their responses would remain anonymous, but single women displayed less ambitious salary and leadership aspirations when they expected classmates would see their answers. Bursztyn and colleagues (2017) interpret these findings as implying that single women "shy away from actions that could improve their careers to avoid signaling undesirable personality traits to the marriage market" (p.20). An alternative interpretation is that some single female MBA students attribute their singleness to a perceived aversion among men against professionally ambitious women. This attribution could be right or wrong but these data tell us more about single women's perceptions than about men's preferences. All in all, it remains unclear how the patterns observed in these cross-sectional experiments are affected by RGE. Yet, such recent findings do suggest that a number of traditional beliefs about gender roles in relationships have persisted despite RGE.

A useful concept for understanding the persistence of gendered patterns of mate selection that incorporates the role of beliefs about both sexes is gender essentialism. Gender essentialism refers to "the notion that men and women are innately and fundamentally different in interests and skills" (England 2010:150; "gender determinism" is a very similar concept, see Tinsley, Howel \& Amanatullah 2015). Using a range of US survey data, Tinsley et al. (2015) demonstrated that gender essentialist attitudes affect mate preferences: men as well as women who think that people's sex strongly determines their behavior preferred a traditional arrangement with the husband as main breadwinner and the wife as chiefly responsible of the home. They also found that women choose professional careers that matched their preferences. Thus, individuals' beliefs about gender condition both their preferences for mates as well as preferences about their own gendered position in heterosexual relationships. 
Taken together, most evidence indicates that mate preferences have moved in large parts of Western populations towards increased gender symmetry and that aversion to female-status dominant relationships has declined but not disappeared. At the same time, what remains clear from recent studies is that women still tend to prefer partners with good economic prospects (and men increasingly do so too). How this affects union formation depends on both the rate at which preferences have changed and on the changing supply of potential mates.

\section{Rates of union formation}

RGE may affect union formation rates through both compositional changes and shifting preferences. For example, if men avoid women with more education, then the compositional shifts implied by RGE could lead to lower rates of union formation among highly educated women. Alternatively, if men increasingly prefer to marry highly educated women, the negative compositional effects may be offset by the changes in preferences. Most existing studies have not been able to address the extent to which trends and patterns in union formation are due to the compositional shifts implied by RGE versus shifting preferences.

Is the evidence consistent with the concern that highly educated women have lower marriage rates because of RGE? Previous research comparing marriage rates across educational groups has found that highly educated men have better union formation prospects than less educated men, but the results for women are more variable, both across time and space (Ono 2003; Blossfeld 2009; Dykstra \& Poortman 2010; Jalovaara 2012; Van Bavel 2012; Grossbard 2015; Bertrand et al. 2016). Studies have documented a reversal of the educational gradient in marriage rates in the US and Canada: college educated women had lower marriage rates in the past, but have become as likely if not more likely to marry compared to those without college education (Goldstein \& Kenney 2001; Fry 2010; Bertrand et al. 2016). Torr (2011) and Budig and Lim (2016) present US evidence indicating that, towards the end of the twentieth century, the higher marriage prospects that long applied to men with more education began to apply to women. Also with respect to earnings the long existing tendency for men with higher earnings to be more likely to marry has extended to women: towards the end of the twentieth century, higher earnings also came to be associated with a higher likelihood of marriage for women (Oppenheimer 1997; Sweeney 2002; Sweeney \& Cancian 2004). 
Evidence from Europe is consistent with these findings; by the end of the twentieth or early twenty-first century, education had become positively associated with union formation for women as it had long been for men (Jalovaara 2012; Perelli-Harris and Lyons-Amos 2016). Bertrand et al. (2016) investigated time trends in a range of countries and found that in the UK, France, Ireland and the Netherlands, highly educated women married less in earlier cohorts, but this gap declined over time, and had reversed by 2010 in the UK and Ireland. In two Nordic countries, Sweden and Finland, a positive ever-married gap between highly and less educated women emerged before 1995. By contrast, in Southern European countries, recent marriage rates are still lower for highly educated women than for women without advanced degrees, and this education gap was relatively stable between 1995 and 2010. These findings are associated with gender norms on the country level: in countries where people tend to agree with the statement that "men have more right to a job than women when jobs are scarce", highly educated women tend to be less likely to be ever-married than women with less education (Bertrand et al. 2016). In a longitudinal study using US data from 1968 to 2012, Pessin (2017) found that the rise gender egalitarianism was initially negatively associated with marriage rates. Yet, for college-educated women, the association became positive when gender egalitarianism continued to rise. Egalitarian attitudes may be expected to become even more common with RGE and the increased labor market participation of women given that children of highly educated and employed women have more egalitarian gender attitudes (Fernandez et al. 2004).

The studies discussed thus far have examined the relationship between education and union formation, but none have explicitly addressed the effect of RGE. De Hauw, Grow and Van Bavel (2017) aimed to do this using data from twenty-eight countries in Europe and found that RGE, after controlling for general cohort trends in union formation, was not associated with an increased likelihood of singlehood for highly educated women. Against expectations, they found that it is low rather than highly educated women (as well as men) who have become more likely to be single with RGE. The authors interpret this as further evidence that earnings potential has become an important asset on the marriage market for women as well as men.

In sum, recent research does not support the concern that highly educated women face worsening prospects on the partnering market. Rather, marriage rates have declined disproportionately for the less educated. Yet, evidence about the changing 
educational gradient in marriage is insufficient to draw conclusions about the causal impact of RGE. None of the studies reviewed thus far provide a counterfactual estimate of what women's marriage rates would have been had RGE not occurred. Although most studies find that highly educated women are now marrying at higher rates than women with less education, the positive educational gradient could be solely due to the worsening prospects of those with less education. The deteriorating economic prospects at the bottom of the labor market may have reduced the marriageability of less educated men and decreased the attractiveness of marriage for this segment of the population (Ruggles 2015; Harknett 2008; Oppenheimer 1994; Lichter et al. 1992). Lundberg et al. (2016) argue that the growing divergence in marriage rates by education is more likely the result of greater demand for relationship commitment among the highly educated because of their intensive joint investments in children rather than changes in the supply of mates or the marriageability of less advantaged men. Increased incentives for marriage thus may have masked potentially negative effects of RGE on rates of union formation for highly educated women.

A few studies have attempted to estimate the causal impact of historical changes in the supply of mates using exogenous shocks to availability or mate characteristics (Abramitzky, DeLavande, and Vasconcelos 2011; Larsen et al. 2015). But to our knowledge only two have attempted to estimate the causal effects of changes in women's status relative to men's on marriage rates. First, using an instrumental variable approach, Bertrand et al. (2015) find that increases in women's relative earnings can account for $29 \%$ of the decline in marriage from 1980 to 2010 . However, Bertrand et al. (2015:590) find that these effects are not present for those with some college or more, only for those with a high school degree or less. Thus, these findings are not consistent with the usual concern that the success of highly educated women diminishes their marriage prospects, but are more consistent with studies suggesting that it is the decline of men's earnings (which results in an increase in less educated women's relative earnings) that drive changes in marriage.

Second, Autor et al.'s (2017) analysis also uses instrumental variables and points to the key role of men's employment in explaining variation in marriage. They examine the effects of increases in women's earnings relative to men's on marriage rates and emphasize the role that the decline of manufacturing employment has had in reducing men's relative earnings and in turn marriage rates. Autor et al. (2017) also find that exogenous shocks that decrease female-intensive employment increase marriage 
rates, but these effects are not as large as those associated with declines in maleintensive employment. These findings harken back to Oppenheimer's (1988) seminal work arguing that changes in men's economic prospects have had more to do with changes in marriage than women's growing economic independence. Given the dearth of research in this area, future research should continue to explore the causal effects of RGE on marriage rates.

\section{SHIFTING PATTERNS OF ASSORTATIVE MATING}

The large changes in educational attainment that have produced RGE in the population are also evident in marriage in Western countries. In recent cohorts where RGE has occurred, wives tend to have the educational advantage when the education of husbands and wives differ (Esteve, García-Román \& Permanyer 2012; Grow \& Van Bavel 2015; Esteve et al. 2016). A recent study of singles, married couples, and cohabitors in 28 European countries found that educational hypogamy is now more common than hypergamy in almost all European countries (De Hauw, Grow \& Van Bavel 2017) as it is in the United States (Schwartz and Mare 2005). These studies suggest that substantial portions of populations in which RGE has occurred are forming partnerships in which wives have more education than their husbands rather than remaining single.

It should be noted, that the growing prevalence of educational hypogamy does not necessarily imply a shift in mate preferences. Rather, changes in observed patterns of spousal resemblance may be driven by changes in population composition alone (Xie, Cheng and Zhou 2015). Using agent-based modeling, Grow and Van Bavel (2015) showed that the shift from educational hypergamy to hypogamy can be explained without assuming any change in male and female mate preferences and may instead emerge with fixed preferences as a result of RGE.

RGE may also affect assortative mating patterns on other dimensions than education, like age and ethnic background, and it could also give rise to migration flows motivated by mate search (Van Bavel 2012). Thus far, no studies have addressed the connection between RGE and age homogamy. Recent studies have examined trends in age homogamy in European countries and find no weakening of age homogamy in past decades (Esteve et al. 2009; Dribe \& Nystedt 2017; Kolk 2015). The effect of RGE on ethnic exogamy and marriage migration in Western countries also remains an under-researched area. Evidence from other parts of the world, mainly 
East-Asian countries, indicates the existence of large cross-sectional marriage markets in which men from the richest countries in the region import brides from poorer countries (Kim 2015; Jones 2012).

The overarching trend toward educational hypogamy may hide the maintenance of more traditional matching patterns on still other dimensions, for example in terms of field of study, occupation, or income (Charles \& Bradley 2002; Van Bavel 2010; Chudnovskaya \& Kashyap 2017). Qian (2016) showed that in most working age and US-born couples where wives have more education than their husbands, husbands still make more money than their wives. Chudnovskaya and Kashyap (2017) present similar findings for Sweden. Thus, while women no longer tend to marry up in education, they still do in terms of earnings. Qian (2016) interprets this as evidence that educational hypogamy does not challenge the higher status of men in marriage because, with delayed marriage, individuals increasingly use income rather than education as the main marker of potential partners' economic prospects. Nevertheless, Qian (2016) also shows that the tendency for women to marry up in income declined between 1980 (based on US Census data) and 2008-2012 (based on American Community Surveys).

An alternative interpretation of the finding that women still marry up in income but not education is that women's education is instrumental in finding a high-income husband. This interpretation is consistent with the growing importance of women's economic prospects in predicting husbands' long-term earnings (Sweeney and Cancian 2004). Thus, the finding that women still marry up in income but not education may not be the result of a preference to avoid status reversal. Instead, both men and women may prefer mates with good economic prospects, which in turn affects spousal selection. Highly educated women are in a better position to match with highincome men. This could also explain Qian's (2016: 15) finding that the tendency for women to marry up in income was not particularly evident among couples in which both spouses had less than a high school education.

In addition, given the gender pay gap to women's disadvantage, even if men preferred wives who outearn them, they would be in short supply (Grow and Van Bavel 2017). Gender inequality in earnings has been lower among the less educated and higher among the highly educated since the 2000s (Goldin et al. 2017), which means that even if highly educated men and women are increasingly tolerant of relationships 
in which wives outearn husbands, attaining this will be increasingly difficult given the disproportionate increase of men's top incomes.

\section{THE DIVISION OF PAID AND UNPAID WORK}

Thus far, our review has addressed how RGE may affect union formation. But what happens after unions are formed? Given positive assortative mating, the gender gap in education is expected to be smaller at the couple level (comparing husbands and wives) than on the population level (comparing men and women at large, which also including singles). Nevertheless, as discussed previously, educational hypogamy is now more common than hypergamy, which suggests that differences in men's and women's education at the population level have translated to differences among couples.

What happens to the organization of paid and unpaid labor in heterosexual relationships when women have more education or income than men? This section reviews arguments and evidence for two perspective about how RGE may affect patterns of relative earnings and unpaid domestic work in heterosexual relationships.

The "economic dependence" or "exchange" model (Gupta 2007; Sullivan 2011) proposes an inverse relationship between a partner's relative earnings potential and time spent on housework: women with more education or earnings than their husbands focus more on paid work, and men are expected to do more unpaid housework. By contrast, "gender display" implies that husbands and wives who are in a relationship where wives have more education or earnings than their husbands neutralize this deviance by "doing gender" (West \& Zimmerman 1987) to highlight their masculinity and femininity and neutralize their non-normative arrangement (Gupta 2007; Schneider 2012). When wives have higher earning potential, they may avoid outearning husbands by working part-time or compensate for higher earnings by doing more housework or by deferring to their husbands' authority in decisionmaking (Bertrand et al. 2015; Tichenor 2005). Conversely, husbands outearned by their wives might refuse to do housework to display their masculinity and compensate for the threat to their gender identity. In this case, gender is said to trump money (Bittman et al. 2003; Kan 2008a), as gender role expectations seem to override the increased bargaining power higher earnings are expected to bring (Tichenor 2005; Sullivan 2011). 


\section{Relative earnings}

A number of studies have shown that gender-deviance neutralization, if it exists in this realm, has not been so strong as to avoid a growing proportion of couples where women earn more than men. Even if gender segregation in fields of study and occupations remains strong, and even if women's and not men's earnings are still negatively affected when couples have children, American and European studies have shown that women's contribution to household income increases with their relative education (Raley et al. 2006; Dribe \& Nystedt 2013; Dotti Sani 2015; Steiber, Berghammer \& Haas 2016; Van Bavel \& Klesment 2017). In a growing share of couples, wives make more money than their husbands (Chenevert 2012; Wang, Parker \& Taylor 2013; Schwartz \& Gonalons-Pons 2016; Klesment and Van Bavel 2017). Male unemployment may be one important reason why wives are breadwinners (Winkler et al. 2005; Vitali \& Arpino 2016), but Schwartz \& Gonalons-Pons (2016) show for the US that the trend towards more women as main earners is just as strong among dualearner couples, so the trend is not driven only by male unemployment. Across the board, wives are more likely to outearn their husbands when they have more education than their husbands (Klesment \& Van Bavel 2017).

As a counterpoint, Bertrand et al. (2015) argue that the distribution of women's relative earnings still provides evidence in support of the gender-deviance neutralization hypothesis. The American data as well as the European data (Klesment and Van Bavel 2017: Figure 1) show a "cliff" in the distribution of women's relative earnings: moving from couples where wives earn almost nothing to those in which wives earn almost $50 \%$ of total couple income, the distribution increases smoothly. Yet, at 50\%, after which point wives would earn more than husbands, the distribution drops drastically, leading to a "cliff" in the middle of the relative income distribution.

Bertrand et al.'s (2015) interpretation is that wives cut back on their labor force participation to avoid outearning their husbands. While men and women increasingly embrace egalitarian ideals about the gender division of labor (Thornton and YoungDeMarco 2001; Cotter, Hermsen, and Vanneman 2011; Gerson 2011; Pedulla and Thébaud 2015; Ruppanner et al. 2017), the male breadwinner norm may be more persistent or stringent than the female homemaker norm. Even in dual-earner families, men's lives are shaped by the normative expectation that they be the main provider and hold primary responsibility for the family's economic wellbeing (Townsend 2010; Sayer et al. 2011; Chesley 2011; Koslowski 2011; Cherlin 2016). 
Consistent with this, one of the ways men maintain an earnings advantage in the US is by increasing their work hours, which in turn prompts their wives to cut back on their own paid work (Cha 2010; Cha and Weeden 2014).

The norm that men should be the main provider offers one possible explanation for the cliff at $50 \%$ in the relative income distribution. But two recent simulation studies show that this cliff can also arise without assuming any deliberate avoidance of wives' earnings advantage. Given the gender pay gap, the cliff can emerge when husbands and wives alike prefer to have more rather than less joint income, even when they do not care about who earns more (Grow and Van Bavel 2017; Bailey et al. 2017). Second, it may also be that the cliff emerges not because women prefer to avoid outearning their husbands but because they may need to work considerably longer hours to outearn them-an outcome that is associated with lower life satisfaction for women (Lepinteur et al. 2016). Third, all these explanations presume that the cliff is real and is not an artifact of peculiarities of the data. Yet, Bailey et al. (2017) show that Bertrand et al.'s American results are highly influenced by a spike in the distribution of spouses' relative income that occurs at exactly 50 percent-a situation that occurs disproportionately among couples in which the sole source of income is a jointly owned business. After the spike is removed, there is no longer a statistically significant drop in wives' relative earnings just above the 50 percent mark. Together, these results call into question interpreting data on patterns of relative earnings to infer preferences. Stated preference data, or data from internet and speed dating studies may be better suited for evaluating these claims.

\section{Unpaid housework}

Evidence points to the effects of RGE on women's relative earnings through its effect on educational assortative mating, but what about the division of unpaid work? Wives still do much more housework than husbands on average (Bianchi et al. 2012; Altintas \& Sullivan 2016), especially in couples with children (Yavorsky et al. 2015). From a relative resources and bargaining perspective, men should do more housework when their wives are more educated than themselves, even more so if their wives outearn them. The gender-deviance neutralization hypothesis makes the opposite prediction. Given that men may be more harshly penalized for transgressing gender norms and it is more socially acceptable for women to move into male domains than the reverse (Ridgeway \& Correll 2004; England 2010; Sayer et al. 2011; Chesley 2011; Levanon \& 
Grusky 2016; Brinton \& Lee 2016), we might expect to see more gender deviance neutralization among men than women (McClintock 2017). It may therefore be particularly men doing less rather than women doing more housework.

Aassve et al. (2014) highlighted the interplay between gender ideology and relative resources in understanding men's participation in housework. They used European Generations and Gender Survey data from the early 2000s to assess the role of gender ideology and relative resources in explaining men's limited contribution to housework. They concluded that gender ideology plays a key role in explaining cross-national differences and that the role of relative resources is conditional on gender ideology. In line with the relative resources perspective, variability in the male share of housework was associated with differences in time availability (the partner who spends less time doing paid work does more housework) and relative earnings (the partner who earns less does more housework), but this only held in gender egalitarian countries.

Bittman et al. (2003) investigated men's participation in housework in late $20^{\text {th }}$ century US and Australia. They found that husbands do more housework as their wives earn a larger share of the joint income, consistent with the relative resources perspective, but only as long as wives did not outearn their husbands. Among the couples where wives outearned their husbands, the association reversed: the more money wives made, the less housework husbands did. More recent work found similar patterns in other data: when earnings deviate from the gendered expectations, it seems to be compensated by "doing gender" at home, with the husband doing relatively less housework and the wife more (Schneider 2012; Besen-Cassino and Cassino 2014).

Yet, recent reassessments of the gender-deviance-neutralization hypothesis cast doubt on whether it (still) aptly describes the relationship between relative earnings and housework. One critique is that many of the initial studies indicating that men do less housework when their wives outearn them were based on data from the 1970s and 1980s, which may not characterize more recently formed marriages. Studies with more recent data have failed to provide evidence for it (Kan 2008a; 2008b; Sullivan 2011; Raley et al. 2012; McClintock 2017; but see Schneider 2012 and Besen-Cassino and Cassino 2014). Women who hold more traditional views about gender do more housework, all else equal, and men with traditional views do less. After accounting for that, it appears that women as well as men do less housework when they earn a larger share of the couple's joint income (Kan 2008a). 
Also, other studies have found that the gender display evident in the initial studies was not a wide-ranging phenomenon but only pertained to a very small fraction of the population, namely to men at the extreme bottom tail of the earnings distribution, often consisting of long-term jobless men with anti-egalitarian gender attitudes (see Sullivan 2011 for a review). Even for these men, gender display applied perhaps more in their responses to survey questionnaires than in their actual behavior, since the evidence of traditional gender display could only be found in measures based on crude recall questions and not in more accurate data based on time-use diaries (Kan 2008b).

Yet other critiques argue that the evidence for gender display is a statistical artifact. Using US data from the early 1990s, Gupta (2007) found that the evidence for gender display in housework was explained by the tendency for wives with low incomes to do more housework than high income wives (who are more often able to outsource housework), combined with the fact that low income wives tend to contribute a higher share of the joint income than more advantaged women. After controlling for the tendency for low income wives to do more housework, evidence for gender display disappeared. Against predictions from the gender-deviance-neutralization perspective, women's absolute and not their relative income was associated with more housework. More recently, McClintock (2017) additionally found that the evidence for gender display results from model misspecifications (not controlling for total housework performed and inappropriately using quadratic specifications). And, finally, studies investigating gender-deviance neutralization in housework among couples have generally failed to take into account substantial differences in time spent on housework that exist prior to union formation. A study using data from the late 1990s and early 2000s in the US, Italy, France and Sweden found that single women spent more time on housework than single men in three of the four countries, Sweden being the exception (Anxo et al. 2011). Accounting for such differences in the assessment of gender-deviance neutralization after union formation would require longitudinal data.

\section{Doing and Undoing Gender}

Evidence from the relative earnings and housework literature suggests that neither the relative resources nor the gender-deviance neutralization approach are capable of fully making sense of the consequences of RGE for relationship dynamics. The relative resource perspective correctly predicts that men increase their contribution to unpaid 
domestic housework and childcare when their female partners earn relatively more (Raley et al. 2012), but does not account for why even women who outearn their male partner still tend to do more (Lyonette \& Crompton 2015: 25-27). Also, even if men have increased their participation in housework and child care, gender segregation in the kind of housework and child care remains strong (Kan et al. 2011). In line with the "doing gender" perspective, women mostly do routine housework and caring for family members while men have increased their contributions disproportionately to nonroutine domestic work. The relative resources perspective predicts that men who earn higher wages relative to their wives should spend less time at home looking after their children. Yet, a study in 14 European countries from 1994 to 2001 found that fathers who spend more time with their children tend to earn more per hour than those who spend less time with their children (Koslowski 2011). In sum, to be informative, the relative resources perspective needs to be enriched with information about gender ideology.

The finding that women's housework is not affected by their earnings relative to their husbands', nor by their husbands' earnings, but rather by their own absolute earnings (Gupta 2007), also runs against predictions from both the relative resources and the gender display perspective. Instead, it calls for an approach that recognizes women's economic autonomy within relationships apart from the comparison with husband's earnings. These findings are also consistent with earlier studies that have shown that women who earn more in absolute terms (rather than compared to their husbands) spend more on the outsourcing of housework (Gupta 2007).

The relative resources approach not only lacks serious consideration of the role played by gender ideology, it has neglected the importance of absolute resources, irrespective of how they compare to (prospective) male partners, to empower people to make autonomous decisions. Such decisions are made in a particular societal context, which includes beliefs about gender. Yet, the gender-deviance neutralization perspective has tended to treat gender ideology as binary and fixed. As a result, it lacks perspective on how the behavior of men and women is not just "doing gender" but may also be "undoing gender" (Deutsch 2007; Risman 2009).

A study of highly educated, professional women using the British Social Attitudes Survey from 2002-2006 yields important insight about how earnings may give women leverage to contest the breadwinner-homemaker model of marriage (Crompton \& Lyonette, 2008; Lyonette \& Crompton 2015). High-earning women 
reported a significantly less traditional division of domestic labor than did other women, even though they often still did more housework than their male partners. Semi-structured interviews with some of the women who earned more than their partners revealed that, although most described themselves as more likely to take responsibility for housework, they disagreed that this was part of an effort to neutralize gender deviance. On the contrary, they appeared to be simultaneously doing and undoing gender, i.e. both performing and challenging the expected gender roles. Their high levels of gender consciousness led them to contest and complain about their male partners' limited performance of housework where they thought the division of labor was unfair.

Complaints and feelings of unfairness about the division of unpaid work may undermine union satisfaction, which may ultimately lead to union dissolution. In a qualitative study of 120 men and women living in the New York metropolitan area, Gerson (2011) found that a majority of young adult women and men alike aspired to have an egalitarian relationship, sharing paid work in the labor market and unpaid work at home. At the same time, despite their shared aspirations, men and women seem to be skeptical about that the egalitarian ideal would be realized. When asked about their fallback strategies, women and men appeared to hold strongly divergent ideals. While the majority of men wanted to revert to traditional gender roles as a fallback plan, most women said they would opt for going it alone if they were faced with that option.

\section{UNION STABILITY}

In the past, marriages in which wives were more educated than their husbands were more likely to dissolve (Blossfeld 2009; Schwartz \& Han 2014). Wives' higher relative earnings were also associated with a higher divorce risk, especially if wives outearned their husbands (Bertrand et al. 2015; Teachman 2010; Schwartz \& Gonalons-Pons 2016). Yet, evidence from the US shows that this has changed: wives who have the educational advantage are no longer less stable than other union types (Schwartz \& Han 2014), and outearning one's husband is no longer associated with marital instability in more recent cohorts (Schwartz \& Gonalons-Pons 2016).

To our knowledge, there are no studies that document the time trends in the association between relative education or earnings and divorce for other countries, but 
there is circumstantial evidence of similar patterns in Europe. Poortman and Kalmijn (2002) found that employed women exhibited higher divorce risk in a cohort of Dutch marriages contracted before 1971, but that this effect decreased over time. Furthermore, divorce rates in Europe tended to be higher among highly educated women in older cohorts, but this has reversed in recent cohorts (Härkönen \& Dronkers 2006). Along these lines, Theunis et al. (forthcoming) investigated how the risk of divorce was associated with educational pairings in a cohort of Belgian marriages contracted between 1986 and 2001 and found that unions in which women have more education than men are more stable in regions where they are relatively common.

The latter finding is consistent with speculation by Schwartz \& Han (2014) that as relationships in which wives have the educational advantage become more common, they may become more acceptable, which in turn supports their stability. Grow et al. (2017) show that an alternative mechanism could also explain the convergence in divorce risks between educationally hypogamous unions and other union types. RGE has changed the availability of attractive alternatives from which highly educated women and men might choose new partners: as a consequence of RGE highly educated women with a less educated partner will encounter fewer highly educated men as potential new partners. By contrast, highly educated men who are with less educated women will be more likely to encounter women with similar high education to form a new union. Grow et al. (2017) demonstrate that this may suffice to explain the convergence in divorce risks between hypogamous unions and other union types.

Another potential explanation for the reduction of the negative effects of wives' relative earnings on marital stability may be related to delayed marriage. An older age at marriage may mean that individuals make fewer major occupation, education, or income changes after marriage that were not part of the original marital bargain (BlairLoy 2001; Oppenheimer 1988), changes which have been found to be associated with divorce (Tzeng and Mare 1995; Weiss and Willis 1997).

The division of paid and unpaid labor may matter more than relative earnings in recent cohorts. Recent evidence from Germany and the UK indicates that the likelihood of divorce is higher for couples in which the combination of wives' paid and unpaid work hours is much more than husbands' (Lepinteur et al. 2016). Killewald's (2016) study of divorce among US couples married before and after 1975 supports the notion that the female homemaker norm has weakened more than the male breadwinner norm. She finds that husbands' full-time employment is associated with 
lower divorce risks in younger as well as in older cohorts, while the negative effects of wives' full-time employment on marital stability declined across cohorts. With respect to unpaid labor, in older cohorts, the risk of divorce was lower when wives did more housework, but less so when wives were employed full-time. In the more recent cohorts, wives who did more housework were slightly more likely to divorce although this estimate was not statistically significant.

Other studies examine the relationship between women's social status and other marital outcomes that may be associated with divorce. A Danish study showed that husbands whose wives outearned them were more likely to use erectile dysfunction medication and that both men and women in couples with breadwinner wives showed increased use of insomnia or anxiety medication. Yet, they also found that men in couples where their fiancées outearned them prior to marriage did not show increased medication usage, suggesting that it may be changes in the marital bargain that are responsible for these effects, not the arrangement per se (Pierce, Dahl \& Nielsen 2013). Relatedly, based on data from the American National Longitudinal Survey of Youth 1997 (NLSY97), Munsch (2015) found that when married men were the main breadwinners, they were more likely to cheat on their wives. By constrast, when women were the main breadwinners, they were less likely to cheat on their husbands. Another American study using data collected in 1992-1994 showed a negative association between an egalitarian division of labor and sexual frequency (Kornrich, Brines \& Leupp 2013). But more recent American studies using data from 2006 found that a more equal division of child care is associated with more sexual and general marital satisfaction, for men as well as women (Carlson et al. 2016a; 2016b).

Similarly, other recent studies using data from the US and Europe find that father's involvement in domestic work is positively associated with marital stability (SigleRushton 2010) and that perceptions of unfairness in housework undermine marital happiness and stability (Frisco \& Williams 2003; Ruppanner, Brandén, and Turunen 2017). However, these relationships vary by social context. For instance, Cooke (2006) found that when husbands do a larger share of housework they are less likely to divorce in the US, but more likely to divorce West Germany. In West Germany, social policy has long reinforced the male breadwinner model and any move away from the separate spheres division of labor was found to be associated with marital instability. This is consistent with the more general observation that women's income increases their ability to negotiate for an egalitarian division of labor and reduces the risk of divorce 
in egalitarian countries but not in inegalitarian ones (Lachance-Grzela and Bouchard 2010; Cooke et al. 2013).

\section{CONCLUSION AND DISCUSSION}

The reversal of the gender gap in education (RGE) has occurred alongside substantial changes in patterns of heterosexual romantic relationships in the US and Europe. As women's educational attainment has exceeded men's in the population, the historical pattern that wives have less education than their husbands has eroded and reversed in many countries. It is likely that at least partly as a result of this, there are now also more couples in which wives earn more than their husbands. Men's and women's preferences for mates have become more gender symmetric and they state less aversion to female status-dominant relationships. While couples in which wives had more education or outearned their husbands were once more likely to divorce, recent research suggests this is no longer the case in recent marriage cohorts in the US and elsewhere.

Despite these shifts, there is also evidence of continued aversion to forming female status-dominant relationships from speed and internet dating data. Even in recent studies, there is evidence that women may downplay their career ambition when seeking mates, that men's self esteem is hurt by the professional success of their female partners (while the reverse is not true), and that both male and female internet daters still tend to avoid pairings in which women have higher status than men. Yet, there are no similar findings from actual long-term relationships.

What does our review of the literature suggest about the two main issues of public concern about RGE? That is, (1) that the reversal will lead to worsening prospects for union formation among highly educated women and (2) that the quality of the relationships in which wives have the higher status will suffer? First, descriptive evidence shows that, despite RGE, highly educated women are not less likely to form unions than less educated ones. Rather, in the US and many European countries, education is now positively associated with union formation for women as well as men. However, studies on the causal effects of RGE on marriage rates are in short supply. It is possible that marriage rates among highly educated women are depressed by RGE relative to what they would be if RGE had not occurred. This is an area for future research. 
Nevertheless, the pattern in the US and Europe has been toward substantial increases in the proportions of couples in which wives have more education than their husbands: while educational homogamy remains dominant, educational hypogamy (wives have more education than their husbands) has become more prevalent than hypergamy (husbands have more education than their wives) in recent decades, not just in the West but also in non-Western countries that have experienced RGE. In turn, the proportion of households where wives earn more than husbands has also increased.

While there are far fewer trend studies of the effects of female status-dominant relationships on divorce and other marriage outcomes, the bulk of the evidence points toward declining negative effects. US research has documented a convergence in divorce risks between hypogamous and other marriages, both in the education and income dimension. In Europe, the educational gradient in divorce has reversed in many countries: while more highly educated women were once more prone to divorce, they are less likely to divorce than women with less education in recent decades. Again, however, the causal mechanisms behind these trends are unclear. Has this occurred because of a causal effect of RGE-e.g., the shortage of highly educated men means that women who are married to men with less education than themselves have fewer attractive alternative marriage partners-or because of broad shifts in egalitarian marriage ideals or changes in the types of people who form these relationships? On many accounts, gender differences have been narrowing although differences remain. For example, research has demonstrated a narrowing of gender differences in mate preferences and, in particular, that men increasingly value good earnings prospects in potential mates.

Changes in housework and childcare show different patterns. Past studies have consistently shown that women do relatively less housework when they earn more up to a point, but there has been disagreement about whether, when wives earn more than their husbands, they compensate by doing more rather than less housework. Although there are exceptions, what is clear is that studies using more recent data are less likely to find evidence of gender display than older studies. Regardless, however, women tend to do more housework than men even when they do outearn them. Whether they do so less today than in the past is an open question. Examining trends in the association between men's and women's relative earnings and the division of housework and childcare is an important area for future research. Also, it remains to 
be seen to what extent highly educated women increasingly search for mates based on their projected domestic and childcare skills (Press 2004; Van Bavel 2012: 141-142).

Another under-researched area is the implications of RGE for ethnic intermarriage and marriage migration. People who do not find a suitable partner in the local marriage market due to skewed sex ratios may begin to explore more distant marriage markets. The marriage squeeze literature acknowledges that migration flows can be an important cause of imbalanced sex ratios, but little attention has been paid to the reverse relationship: RGE may give rise to migration flows that are at least partly motivated by the search for mates. Furthermore, RGE tends to be even more pronounced among ethnic minorities in Europe (Van Bavel 2012) and occurred much earlier among African Americans in the US compared to whites (McDaniel et al. 2011). Such imbalances may stimulate not only marriage migration but also ethnic exogamy (Van Bavel 2012; Keels and Harris 2014). More generally, more research is needed on the interplay between local and national or cross-national marriage markets.

In addition, research about the implications of RGE for family life has largely neglected the distinction between marriage and unmarried cohabitation. While unmarried cohabitation has emerged as both an alternative and a prelude to marriage (Perelli-Harris \& Sánches Gassen 2012; Hiekel, Liefbroer \& Poortman 2014; Lundberg et al 2016), most theorizing about the implications of changes in the sex ratio for union formation addresses either marriage, or makes no distinction between formal marriage and unmarried cohabitation (see Grossbard 2016 for an exception). We are not aware of any studies yet that specifically address the implications of RGE for the choice between marriage and cohabitation.

\section{REFERENCES}

Aassve A, Fuochi G, Mencarini L. 2014. Desperate Housework: Relative Resources, Time Availability, Economic Dependency, and Gender Ideology Across Europe. J. Fam. Issues. 35(8):1000-1022

Abramitzky R, Delavande A, Vasconcelos L. 2011. Marrying Up : The Role of Sex Ratio in Assortative Matching. Am. Econ. J. Appl. Econ. 3(3):124-57

Ainsworth BYC. 2015. Sex redefined. The idea of two sexes is simplistic. Nature. 518:28891

Angrist J. 2002. How do sex ratios affect marriage and labor. Q. J. Econ. 117(3):997-1038 
Anxo D, Mencarini L, Pailhé A, Solaz A, Tanturri ML, Flood L. 2011. Gender differences in time use over the life course in France, Italy, Sweden, and the US. Fem. Econ. 17(3):159-95

Akers DS. 1967. On measuring the marriage squeeze. Demography. 4(2):907-24

Altintas E, Sullivan O. 2016. Fifty years of change updated: Cross-national gender convergence in housework. Demogr. Res. 35(August):455-70

Attané I. 2006. The Demographic Impact of a Female in China, 2000-2050. Popul. Dev. Rev. 32(4):755-70

Autor DH, Dorn D, Hanson GH. 2017. When Work Disappears: Manufacturing Decline and the Falling Marriage-Market Value of Men. NBER Working Paper. w23173, Cambridge (Mass.)

Bailey M, Binder A, Lam D. 2017. Do husbands want to be shorter than their wives? The hazards of inferring preferences from marriage market outcomes. Paper presented at the Annual Meeting of the Population Association of America, Chicago, April 24-29, 2017.

Beck, B. 2011. Closing the Gap. The Economist, Nov. 26 ${ }^{\text {th }} .2011$.

Bertrand M, Kamenica E, Pan J. 2015. Gender identity and relative income within households. Q. J. Econ. 130(2):571-614

Bertrand M, Cortes P, Olivetti C, Pan J. 2016. Social Norms , Labor Market Opportunities , and the Marriage Market Penalty for Skilled Women. NBER Working Paper No. 22015.

Besen-Cassino Y, Cassino D. 2014. Division of House Chores and the Curious Case of Cooking : The Effects of Earning Inequality on House Chores among Dual- Earner Couples. AboutGender. Int. J. Gend. Stud. 3(6):25-53

Bianchi SM, Sayer LC, Milkie MA, Robinson JP. 2012. Housework: Who did, does or will do it, and how much does it matter? Soc. Forces. 91(1):55-63

Birger, J. 2015. Date-Onomics: How dating became a lopsided numbers game. New York: Workman Publishing.

Bittman, M., England, P., Sayer, L., Folbre, N., \& Matheson, G. (2003). When Does Gender Trump Money? Bargaining and Time in Household Work. American Journal of Sociology 109(1):186-214.

Blair-Loy, M. 2001. Cultural Constructions of Family Schemas: The Case of Women Finance Executives. Gender \& Society 15(5):687-709.

Blossfeld H-P. 2009. Educational Assortative Marriage in Comparative Perspective. Annu. Rev. Sociol. 35(1):513-30

Brand JE, Davis D. 2011. The Impact of College Education on Fertility: Evidence for Heterogeneous Effects. Demography. 48(3):863-87 
Brinton MC, Lee D-J. 2016. Gender-role ideology, labor market institutions, and postindustrial fertility. Popul. Dev. Rev. 42(3):405-33

Buchmann, C., DiPrete, T. A., \& McDaniel, A. (2008). Gender inequalities in education. Annu. Rev. Sociol, 34:319-337.

Budig MJ, Lim M. 2016. Cohort Differences and the Marriage Premium: Emergence of Gender-Neutral Household Specialization Effects. J. Marriage Fam. 78(5):1352-70

Bukodi E, Goldthorpe JH, Halpin B, Waller L. 2016. Is Education Now Class Destiny? Class Histories across Three British Birth Cohorts. Eur. Sociol. Rev. jcw041

Bursztyn L, Fujiwara T, Pallais A. 2017. “Acting Wife”: Marriage Market Incentives and Labor Market Investments. NBER Work. Pap. 23043.

Buss DM, Shackelford TK, Kirkpatrick L a, Larsen RJ. 2001. A half century of mate preferences: The cultural evolution of values. J. Marriage Fam. 63(2):491-503

Carlson DL, Miller AJ, Sassler S, Hanson S. 2016a. The gendered division of housework and couples' sexual relationships: A reexaminiation. Journal of Marriage and Family 78(4):975-95.

Carlson DL, Hanson S, Fitzroy A. 2016b. The division of child care, sexual intimacy, and relationship quality in couples. Gend. Soc. 30(3):442-66

Cha, Y. 2010. Reinforcing separate spheres: The effect of spousal overwork on men's and women's employment in dual-earner households. American Sociological Review, 75(2), 303-29

Cha Y, Weeden KA. 2014. Overwork and the Slow Convergence in the Gender Gap in Wages. Am. Sociol. Rev. 79(3):457-84

Charles M, Bradley K. 2002. Equal but separate? A cross-national study of sex segregation in higher education. Am. Sociol. Rev. 67(4):573-99

Chenevert R. 2012. Changing levels of spousal education and labor force supply. U.S. Census Bureau working paper, The Survey of Income and Program Participation, no. 263.

Cherlin AJ. 2016. A Happy Ending to a Half-Century of Family Change ? Popul. Dev. Rev. 42(1):121-29

Chesley N. 2011. Stay-at-Home Fathers and Breadwinning Mothers: Gender, Couple Dynamics, and Social Change. Gend. Soc. 25(5):642-64

Chudnosvkaya M, Kashyap R. 2017. Is the end of educational hypergamy the end of hypergamy? Evidence from Sweden. Stockholm Research Reports in Demography. 2017:25, Stockholm, Sweden, Department of Sociology, Demography Unit.

Cooke LP. 2006. "Doing Gender" in Context: Household Bargaining and the Risk of Divorce in Germany and the United States. Am. J. Sociol. 112(2):442-72 
Cooke LP, Erola J, Evertsson M, Mencarini L, Mignot J. 2013. Labor and Love : Wives ' Employment and Divorce Risk in its Socio-Political Context. Soc. Polit. 20(4):482-509

Cotter D, Hermsen JM, Vanneman R. 2011. The end of the gender revolution? Gender role attitudes from 1977 to 2008. AJS. 117(1):259-89

Crompton R, Lyonette C. 2008. Who does the housework? The division of labour within the home. In British Social Attitudes. The 24th Report, eds. A Park, J Curtice, K Thomson, M Philips, M Johnson, pp. 53-80. London: Sage

Das Gupta M. 2006. Cultural versus biological factors in explaining Asia's "Missing Women": Response to Oster. Popul. Dev. Rev. 32(2):328-32

De Hauw, Yolien, André Grow, and Jan Van Bavel. 2017. The reversed gender gap in education and assortative mating in Europe, European Journal of Population.

Deutsch FM. 2007. Undoing Gender. Gend. Soc. 21(1):106-27

DiPrete TA, Buchmann C. 2006. Gender-specific trends in the value of education and the emerging gender gap in college completion. Demography. 43(1):1-24

DiPrete TA, Buchmann C. 2013. The Rise of Women. The Growing Gender Gap in Education and What It Means for American Schools. New York (N.Y.): Russell Sage Foundation

Dotti Sani GM. 2015. Within-couple inequality in earnings and the relative motherhood penalty. A cross-national study of european countries. Eur. Sociol. Rev. 31(6):667-82

Dribe M, Nystedt P. 2013. Educational Homogamy and Gender-Specific Earnings: Sweden, 1990-2009. Demography. 50(4):1197-1216

Dribe M, Nystedt P. 2017. Age homogamy, gender, and earnings: Sweden 1990-2009. Soc. Forces. 1-25.

Dykstra PA, Poortman A-R. 2010. Economic Resources and Remaining Single: Trends Over Time. Eur. Sociol. Rev. 26(3):277-90

England P. 2010. The Gender Revolution: Uneven and Stalled. Gend. Soc. 24(2):149-66

England P, Bearak J, Budig MJ, Hodges MJ. 2016. Do Highly Paid, Highly Skilled Women Experience the Largest Motherhood Penalty? Am. Sociol. Rev. 81(6):1161-89

Esping-Andersen G. 2009. The Incomplete Revolution. Adapting to Women's New Roles. Cambridge, UK: Polity Press

Esping-Andersen G, Boertien D, Bonke J, Gracia P. 2013. Couple specialization in multiple equilibria. Eur. Sociol. Rev. 29(6):1280-94

Esping-Andersen G, Billari FC. 2015. Re-theorizing Family Demographics. Popul. Dev. Rev. 41(1):1-31 
Esteve A, Cortina C, Cabré A. 2009. Long term trends in marital age homogamy patterns: Spain, 1922-2006. Population. 64(1):173-202

Esteve A, García-Román J, Permanyer I. 2012. The gender-gap reversal in education and its effect on union formation: the end of hypergamy? Popul. Dev. Rev. 38(3):535-46

Esteve A, Schwartz CR, Van Bavel J, Permanyer I, Klesment M, Garcia J. 2016. The End of Hypergamy: Global Trends and Implications. Popul. Dev. Rev. 42(4):615-25

Fernández R, Fogli A, Olivetti C, Fernandez R, Bandiera O, et al. 2004. Mothers and Sons: Preference Formation and Female Labor Force Dynamics. Q. J. Econ. 119(4):1249-99

Fernández R, Guner N, Knowles J. 2005. Love and money: a theoretical and empirical analysis of household sorting and inequality. Q. J. Econ. 120(1):273-344

Fisman R, Iyengar SS, Kamenica E, Simonson I. 2006. Gender differences in mate selection: Evidence from a speed dating experiment. Q. J. Econ. 121(May):673-97

Fossett MA, Kiecolt KJ. 1991. A Methodological Review of the Sex Ratio : Alternatives for Comparative Research. J. Marriage Fam. 53(4):941-57

Frisco ML, Williams K. 2003. Perceived Housework Equity, Marital Happiness, and Divorce in Dual-Earner Households. J. Fam. Issues. 24(1):51-73

Fry R. 2010. The Reversal of the College Marriage Gap. Washington DC: Pew Research Center.

Gerson K. 2011. The Unfinished Revolution. Coming of Age in a New Era of Gender, Work, and Family. Oxford: Oxford University Press

Glick PC, Heer DM, Beresford JC. 1963. Family formation and family composition: trends and prospects. In Sourcebook in Marriage and the Family, ed. MB Sussman. New York (N.Y.): Houghton Mifflin Co.

Goldin C. 2006. The quiet revolution that transformed women's employment, education, and family. Am. Econ. Rev. 96(2):1-21

Goldin C, Kerr SP, Olivetti C, Barth E. 2017. The expanding gender earnings gap: Evidence from the LEHD-2000 census. Am. Econ. Rev. 107(5):110-14

Goldscheider F, Bernhardt E, Lappegård T. 2015. The Gender Revolution : A Framework for Understanding Changing Family and Demographic Behavior. Popul. Dev. Rev. 41(2):207-39

Goldstein JR, Kenney CT. 2001. Marriage delayed or marriage forgone? New cohort forecasts of first marriage for U.S. women. Am. Sociol. Rev. 66(4):506-19

Goode WJ. 1963. World Revolution and Family Patterns. New York, NY: Free Press. 
Grossbard S. 2015. The Marriage Motive: A Price Theory of Marriage. How Marriage Markets Affect Employment, Consumption, and Savings. New York: Springer

Grossbard S. 2016. Marriage and Marriage Markets. IZA Discussion Paper No. 10312. Bonn (Germany): IZA Institute for the Study of Labor.

Grow A, Van Bavel J. 2015. Assortative Mating and the Reversal of Gender Inequality in Education in Europe: An Agent-Based Model. PLoS One. 10(6):e0127806

Grow A, Schnor C, Van Bavel J. 2017. The reversal of the gender gap in education and relative divorce risks: a matter of alternatives? Popul. Stud. 71(S1):S15-34

Grow A, Van Bavel J. 2017. The income cliff in households? Insights from Agent-Based Computational Modelling. Paper presented at the 13th conference of the European Sociological Association, Athens, Greece, 29 August - 1 September 2017.

Gupta S. 2007. Autonomy, Dependence, or Display? The Relationship Between Married Women's Earnings and Housework. J. Marriage Fam. 69(2):399-417

Guttentag M, Secord PF. 1983. Too Many Women? The Sex Ratio Question. Beverly Hills, CA: Sage

Hajnal J. 1953. Age at marriage and proportions marrying. Population Studies. 7(2):111-36

Härkönen J, Dronkers J. 2006. Stability and change in the educational gradient of divorce. A comparison of seventeen countries. Eur. Sociol. Rev. 22(5):501-17

Hiekel N, Liefbroer AC, Poortman A-R. 2014. Understanding Diversity in the Meaning of Cohabitation Across Europe. Eur. J. Popul. 30(4):391-410

Hitsch, G.J. Hortaçsu, A. Ariely D. 2013. Online Dating Matching and Sorting in. Am. Econ. Assoc. 100(1):130-63

Hochschild AR. 1989. The Second Shift: Working Parents and the Revolution at Home. New York (N.Y.): Viking Penguin

Jalovaara M. 2012. Socio-economic resources and first-union formation in Finland, cohorts born 1969-81. Popul. Stud. 66(1):69-85

Janssens A. 1997. The Rise and Decline of the Male Breadwinner Family? An Overview of the Debate. Int. Rev. Soc. Hist. 42(Supplement):1-23

Jones GW. 2005. The "flight from marriage" in South-East and East Asia. J. Comp. Fam. Stud. 36(1):93-119

Jones, Gavin W. 2012. "International Marriage in Asia: What Do We Know, and What Do We Need to Know?" In Doo-Sub Kim (ed.), Cross-border Marriage: Global Trends and Diversity. Seoul: Korea Institute for Health and Social Affairs, pp. 13-49. 
Kalmijn M. 1998. Intermarriage and homogamy: causes, patterns, trends. Annu. Rev. Sociol. (24):395-421

Kan, M-Y. 2008a. Does gender trump money? Housework hours of husbands and wives in Britain. Work. Employ. Soc. 22(1):45-66

Kan MY. 2008b. Measuring housework participation: The gap between "stylised" questionnaire estimates and diary-based estimates. Soc. Indic. Res. 86(3):381-400

Kan M-Y, Hertog E. 2017. Domestic division of labour and fertility preference in China, Japan, South Korea, and Taiwan. Demogr. Res. 36(February):557-88

Kashyap, R., Esteve, A., \& García-Román, J. 2015. Potential (mis) match? Marriage markets amidst sociodemographic change in India, 2005-2050. Demography, 52(1), 183-208

Keels, M, and Harris, K. 2014. Intercultural dating at predominantly White universities in the United States: The maintenance and crossing of group borders. Societies 4.3:363-379.

Killewald A. 2016. Money, Work, and Marital Stability: Assessing Change in the Gendered Determinants of Divorce. Am. Sociol. Rev. 81(4):696-719

Kim, D.S. 2015. International Marriage of Koreans and Adaptation of Foreign Spouses. Seoul: Jipmoondang.

Klesment M, Van Bavel J. 2017. The Reversal of the Gender Gap in Education, Moterhood, and Women as Main Earners in Europe. Eur. Sociol. Rev. 33:1-15

Kolk M. 2015. Age Differences in Unions: Continuity and Divergence Among Swedish Couples Between 1932 and 2007. Eur. J. Popul. 31(4):365-82

Kornrich S, Brines J, Leupp K. 2013. Egalitarianism, Housework, and Sexual Frequency in Marriage. Am. Sociol. Rev. 78(1):26-50

Koslowski AS. 2011. Working fathers in Europe: Earning and caring. Eur. Sociol. Rev. 27(2):230-45

Lachance-Grzela M, Bouchard G. 2010. Why Do Women Do the Lion's Share of Housework? A Decade of Research. Sex Roles. 63(11):767-80

Larsen MF, McCarthy TJ, Moulton JG, Page ME, Patel AJ. 2015. War and Marriage: Assortative Mating and the World War II GI Bill. Demography. 52(5):1431-61

Lepinteur A, Fleche S, Powdthavee N. 2016. My Baby Takes the Morning Train: Gender Identity, Fairness, and Relative Labor Supply Within Households. IZA Discussion Paper No. 10382

Levanon A, Grusky DB. 2016. The Persistence of Extreme Gender Segregation in the Twenty-first Century. Am. J. Sociol. 122(2):573-619 
Lundberg S, Pollak RA, Stearns J. 2016. Family Inequality: Diverging Patterns in Marriage, Cohabitation, and Childbearing. J. Econ. Perspect. 30(2):79-102

Lyonette C, Crompton R. 2015. Sharing the load? Partners' relative earnings and the division of domestic labour. Work. Employ. Soc. 29(1):23-40

McClintock EA. 2017. Occupational Sex Composition and Gendered Housework Performance: Compensation or Conventionality? J. Marriage Fam. 79(2):475-510

McDaniel, A., DiPrete, T. A., Buchmann, C., \& Shwed, U. 2011. The black gender gap in educational attainment: Historical trends and racial comparisons. Demography, 48(3), 889-914

McDonald P. 2000. Gender equity in theories of fertility transition. Popul. Dev. Rev. 26(3):427-39

Moore F, Cassidy C, Perrett DI. 2010. The effects of control of resources on magnitudes of sex differences in human mate preferences. Evol. Psychol. 8(4):720-35

Mundy L. 2012. The richer sex: How the new majority of female breadwinners is transforming our culture. New York: Simon and Schuster.

Munsch CL. 2015. Her Support, His Support: Money, Masculinity, and Marital Infidelity. Am. Sociol. Rev. 80(3):469-95

Oppenheimer, VK. 1988. A Theory of Marriage Timing American Journal of Sociology 94(3): 563-591.

Oppenheimer VK. 1997. Women's Employment and the Gain to Marriage : The Specialization and Trading Model. Annu. Rev. Sociol. 23:431-53

Ono H. 2003. Women's economic standing, marriage timing, and cross-national contexts of gender. J. Marriage Fam. 65(2):275-86

Pedulla DS, Thébaud S. 2015. Can We Finish the Revolution? Gender, Work-Family Ideals, and Institutional Constraint. Am. Sociol. Rev. 80(1):116-39

Perelli-Harris B, Lyons-Amos M. 2016. Partnership patterns in the United States and across Europe: The role of education and country context. Soc. Forces. 95(1):251-82

Pessin L. 2017. Changing Gender Norms and Marriage Dynamics in the United States. $J$. Marriage Fam. DOI: 10.1111/jomf.12444

Pierce L, Dahl MS, Nielsen J. 2013. In sickness and in wealth: psychological and sexual costs of income comparison in marriage. Personal. Soc. Psychol. Bull. 39(3):359-74

Poortman A-R, Kalmijn M. 2002. Women's Labour Market Position and Divorce in the Netherlands : Evaluating Economic Interpretations of the Work Effect. Eur. J. Popul. 18(2):175-202 
Press JE. 2004. Cute Butts and Housework : A Gynocentric Theory of Assortative Mating. J. Marriage Fam. 66(4):1029-33

Qian Y. 2016. Gender Asymmetry in Educational and Income Assortative Marriage. $J$. Marriage Fam.

Raley SB, Mattingly MJ, Bianchi SM. 2006. How Dual Are Dual-Income Couples? Documenting Change From 1970 to 2001. J. Marriage Fam. 68(1):11-28

Raley S, Bianchi SM, Wang W. 2012. When Do Fathers Care ? Mothers 'Economic Contri bution and Fathers' Involvement in Child Care. Am. J. Sociol. 117(5):1422-59

Ratliff KA, Oishi S. 2013. Gender differences in implicit self-esteem following a romantic partner's success or failure. J. Pers. Soc. Psychol. 105(4):688-702

Raymo JM, Park H, Xie Y, Yeung WJ. 2015. Marriage and Family in East Asia: Continuity and Change. Annu. Rev. Sociol. 41:471-92

Ridgeway CL, Correll SJ. 2004. Unpacking the Gender System: A Theoretical Perspective on Gender Beliefs and Social Relations. Gend. Soc. 18(4):510-31

Risman BJ. 2009. From Doing To Undoing: Gender as We Know It. Gend. Soc. 23(1):81-84.

Rosin, H. 2012. The End of Men: And the Rise of Women. New York: Penguin.

Ruppanner L, Brandén M, Turunen J. 2017. Does Unequal Housework Lead to Divorce? Evidence from Sweden. Sociology. 1-20

Ruppanner L, Bernhardt E, Brandén M. 2017. Division of housework and his and her view of housework fairness: A typology of Swedish couples. Demogr. Res. 36(February):501-24

Ruggles, S. 2015. Patriarchy, Power, and Pay: The Transformation of American Families, 1800-2015. Demography. 52(6):1797-1823.

Sayer LC, England P, Allison PD, Kangas N. 2011. She Left, He Left: How Employment and Satisfaction Affect Women's and Men's Decisions to Leave Marriages. Am. J. Sociol. 116(6):1982-2018

Schmitt DP. 2012. When the difference is in the details: A critique of Zentner and Mitura (2012) "stepping out of the Caveman's shadow: Nations' gender gap predicts degree of sex differentiation in mate preferences." Evol. Psychol. 10(4):720-26

Schneider D. 2012. Gender Deviance and Household Work: The Role of Occupation. Am. J. Sociol. 117(4):1029-72

Schoen R. 1983. Measuring the tightness of a marriage squeeze. Demography. 20(1):61-78

Schofer E, Meyer JW. 2005. The Worldwide Expansion of Higher Education in the Twentieth Century. Am. Sociol. Rev. 70(6):898-920 
Schwartz CR. 2013. Trends and Variation in Assortative Mating: Causes and Consequences. Annu. Rev. Sociol. 1-41

Schwartz CR, Mare RD. 2005. Trends in educational assortative marriage from 1940 to 2003. Demography. 42(4):621-46

Schwartz CR, Han H. 2014. The Reversal of the Gender Gap in Education and Trends in Marital Dissolution. Am. Sociol. Rev. 79(4):605-29.

Schwartz CR, Gonalons-Pons P. 2016. Trends in relative earnings and marital dissolution: are wives who outearn their husbands still more likely to divorce? RSF Russell Sage Found. J. Soc. Sci. 2(4):218-36

Sen A. 1992. Missing women. Social inequality outweighs women's survival advantage in Asia and north Africa. Br. Med. J. 304:587-88

Sigle-Rushton W. 2010. Men's Unpaid Work and Divorce: Reassessing Specialization and Trade in British Families. Fem. Econ. 16(2):1-26

Steiber N, Berghammer C, Haas B. 2016. Contextualizing the Education Effect on Women's Employment: A Cross-National Comparative Analysis. J. Marriage Fam. 78(1):246-61

Stewart-Williams S, Thomas AG. 2013. The ape that thought it was a peacock: does evolutionary psychology exaggerate human sex differences? Psychol. Inq. 24(3):137-68

Sullivan O. 2011. An End to Gender Display Through the Performance of Housework? A Review and Reassessment of the Quantitative Literature Using Insights From the Qualitative Literature. J. Fam. Theory Rev. 3(1):1-13

Sullivan O, Billari FC, Altintas E. 2014. Fathers' Changing Contributions to Child Care and Domestic Work in Very Low-Fertility Countries: The Effect of Education. J. Fam. Issues. 35(8):1-18

Sweeney MM. 2002. Two decades of family change: The shifting economic foundations of marriage. Am. Sociol. Rev. 67(1):132-47

Sweeney MM, Cancian M. 2004. The changing importance of white woman's economic prospects for assortative mating. J. Marriage Fam. 66(4):1015-28

Tach L. 2015. Social Mobility in an Era of Family Instability and Complexity. Ann. Am. Acad. Pol. Soc. Sci. 657(January):83-96

Tauch C., Rauhvargers A. 2002. Survey on Master Degrees and Joint Degrees in Europe. Brussels: EUA.

Teachman J. 2010. Wives' Economic Resources and Risk of Divorce. J. Fam. Issues. 31(10):1305-23

Theunis L, Schnor C, Willaert D, Van Bavel J. (forthcoming) His and her education and marital dissolution: adding a contextual dimension. Eur. J. Popul. 1-33 
Thornton A, Young-DeMarco L. 2001. Four decades of trends in attitudes toward family issues in the United States: The 1960s through the 1990s. J. Marriage Fam. 63(4):100937

Tichenor V. 2005. Maintaining men's dominance: Negotiating identity and power when she earns more. Sex Roles. 53(3-4):191-205

Tinsley CH, Howell TM, Amanatullah ET. 2015. Who should bring home the bacon? How deterministic views of gender constrain spousal wage preferences. Organ. Behav. Hum. Decis. Process. 126:37-48

Torr BM. 2011. The Changing Relationship between Education and Marriage in the United States, 1940-2000. J. Fam. Hist. 36(4):483-503

Townsend, N. 2010. Package deal: Marriage, work and fatherhood in men's lives. Temple University Press

Tzeng, J.M. and R.D. Mare. 1995. Labor Market and Socioeconomic Effects on Marital Stability. Social Science Research 24(4):329-351

Van Bavel J. 2010. Choice of study discipline and the postponement of motherhood in Europe: the impact of expected earnings, gender composition, and family attitudes. Demography. 47(2):439-58

Van Bavel J. 2012. The reversal of gender inequality in education, union formation, and fertility in Europe. Vienna Yearb. Popul. Res. 2012:

Van Bavel J, Klesment M. 2017. Educational Pairings, Motherhood, and Women's Relative Earnings in Europe. Demography. Published online https://doi.org/10.1007/s13524$\underline{017-0621-\mathrm{Z}}$

Van der Ploeg F, Veugelers R. 2008. Towards evidence-based reform of European Universities, CESifo Economic Studies 54(2): 99-120.

Vitali A, Arpino B. 2016. Who brings home the bacon? The influence of context on partners' contributions to the household income. Demogr. Res. 35(41):1213-44

Waismel-Manor R, Levanon A, Tolbert PS. 2016. The Impact of Family Economic Structure on Dual-Earners: Career and Family Satisfaction. Sex Roles. 75(7-8):349-62

Wang W, Parker K, Taylor P. 2013. Breadwinner Moms. Washington DC: Pew Research Center.

West C, Zimmerman DH. 1987. Doing gender. Gend. Soc. 1(2):125-51

Whitehead, B.D. 2002. Why There Are no Good Men Left: The Romantic Plight of the New Single Woman. New York: Broadway Books.

Xie Y, Cheng S, Zhou X. 2015. Assortative mating without assortative preference. Proc. Natl. Acad. Sci. 112(19):5974-78 
Yavorsky JE, Kamp Dush CM, Schoppe-Sullivan SJ. 2015. The Production of Inequality: The Gender Division of Labor Across the Transition to Parenthood. J. Marriage Fam. 77(3):662-79

Weiss, Y and RJ Willis. 1997. Match Quality, New Information, and Marital Dissolution. Journal of Labor Economics 15(1):S293-S329.

Winkler AE, McBride TD, Andrews C. 2005. Wives who Outearn their Husbands: A Transitory or Persistent Phenomenon for Couples? Demography. 42(3):523-35

Zentner M, Mitura K. 2012. Stepping out of the caveman's shadow: Nations' gender gap predicts degree of sex differentiation in mate preferences. Psychol. Sci. 23(10):1176-85

Zentner M, Eagly AH. 2015. A sociocultural framework for understanding partner preferences of women and men: Integration of concepts and evidence. Eur. Rev. Soc. Psychol. 26(1):328-73 